\title{
Public Policies in the Rural Area of São João del-Rei: An inhabitants' view
}

\author{
Larissa Medeiros Marinho dos Santos \\ Johnny da Costa Barbosa \\ Rodrigo Meireles dos Santos \\ Anna Beatriz Ribeiro Paiva Netto
}

${ }^{1}$ Universidade Federal de São João Del Rei, São João Del Rei, MG, Brazil

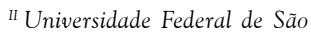

(D) João Del Rei, São João Del Rei, MG, Brazil

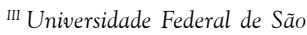
D João Del Rei, São João Del Rei, MG, Brazil

IV Universidade Federal de São (D) João Del Rei, São João Del Rei, MG, Brazil

\begin{abstract}
This work aims to investigate the view the inhabitants of the Rural Area of São João del-Rei have about the environment surrounding them and about the public policies for the region. The methodology used is founded on Qualitative Epistemology, focusing on the participants' subjectivity. Interviews were made with eleven participants from six rural communities based on their life history. The analysis of the data was performed based on concepts from Environmental Psychology and from the Bioecological Model of Human Development. The results indicated that the inhabitants see themselves as inhabitants of rural areas; they described the existing public policies and pointed out the needs found in this context. The need of formulating adequate public policies for the scenario presented is considered.
\end{abstract}

Keywords: Rural Area; Environmental Psychology; Public Policies; Developmental Psychology.

São Paulo. Vol. 23, 2020

Original Article

DOI: http://dx.doi.org/10.1590/1809-4422asoc20180163r3vu2020L5AO 


\section{Introduction}

The focus of this research was the analysis of the relationships between the inhabitants of the Rural Area (ZR) of the São João del-Rei municipality and the environment surrounding them. The work was based on the theories of Environmental Psychology and on the Bioecological Approach to Human Development (BRONFENBRENNER, 2011). The aim was to identify and to analyze the perceptions of these persons regarding their environment, considering the public policies in the region and how such a context influences rural development (KAGEYAMA, 2004a; 2004b) and the human development of those living in those regions. In this proposal, public policies are understood as "a set of governmental actions and decisions, directed to solving (or not) the problems of society [...]". (SEBRAE MG, 2008, p. 15).

According to data from the Brazilian Institute of Geography and Statistics (IBGE) (2010), the total Population of Brazil is composed of $190,755,799$ people, $15.6 \%$ of whom living in the rural area, that is, about 29,757,906 people. Even with large numbers of inhabitants, the rural area lacks greater action by the public bodies, once few - structural and financial - resources reach these places. Unfortunately, the IBGE studies on this parcel of the population may be considered outdated and not very efficient for understanding the specific needs and characteristics of each rural context existing in the country, due to their heterogeneity (SOUZA; BRANDENBURG, 2010).

The rural area has particularities as compared to the urban environment, being different both in its physical-environmental aspects, and in social aspects, which leads to the existence of distinct demands and needs of its population. Therefore, the government actions and the formulation of public policies to assist the rural area cannot be established in the same way as occurs for the urban environment. It is necessary to understand these regions, consider their particularities and the inhabitants' demands.

\section{Theoretical Foundation}

\section{What is rural?}

Decree Law number 311, of 1938, is the Brazilian law that defines what is urban and what is rural (BRASIL, 1938). The law, from the Vargas period, states that whatever is not urban is considered rural. According to the Decree, it is the municipalities' duty to organize their territory and to establish which areas are located within the urban area and which are in the rural one.

Although Brazil adopts the 1938 Decree, the literature allows observing the existence of other classifications of rural made by world organisms, such as the United Nations (UN), the Organisation for Economic Co-operation and Development (OECD) and the former Commission of the European Communities (CEC). To classify rural, the UN considers the preponderance of functions regarding the rural area by the set of inhabitants exerting an economic function. The OECD uses the demographic classification, in which a place having its density greater than 150 inhabitants $/ \mathrm{km}^{2}$ is classified as urban and the CEC considers as rural area the places where occupations are varied, including: the 
culture in natural and cultivated places, the inhabitants, settlements, small and mediumsized towns, and considers areas with industrialization as rural regions (GOMES, 2013).

The Decree Law regulating rural areas in Brazil was implemented at a time when most of the Brazilian population lived in rural areas, besides delegating the definition of what is meant by rural/urban to the municipal entities. Favareto and Abromovay (2009) point out that delegating the definition to the municipalities generates a problem to the IBGE work, hindering the comparison between territories. As a result, it is necessary to update this regulation to the current time. This regulation should at least consider "the populational size of the municipality, its population density and its location" (FAVARETO; ABROMOVAY, 2009, p. 11).

It can be observed, however, that in the public policies there is a concern, mainly directed to the agrarian aspect, with an invisibility to what is rural (SOUZA; BRANDENBURG, 2010). Authors in the area list examples that date back to the Vargas government, going through the military dictatorship, through the 1988 Federal Constitution, up to the current days, in which the policies are generally marked by agricultural financing, which aims to increase the agricultural production in Brazil, without actually showing a concern about the other demands of the population in the rural areas (LEITÃO et al. 2009; PEREIRA, 2010; SILVA, 2012; RAMOS, 2015).

With the passing of time, the countryside underwent a great revolution in its structures, including modifications in the population, the implementation of technologies in the production system, changes in the society view regarding nature - fabricated nature of the rural world -, proximity to the urban area (ORTEGA; FONSECA, 2009; PEREIRA, 2010). As pointed out by Souza and Brandenburg (2010), these are processes that directly influence the existence of rurality. As highlighted by Favareto (2007), the problem is that the idea of rurality only seems to exist as from its opposing pair, urbanity - the city; yet these relationships do not occur as simply as they may seem to.

Even if the rural areas may have some characteristics attributed to cities, this does not mean they have ceased to be rural. Therefore, the meaning of rural is connected to cultural issues, to movement, to local connections and traditions. According to Wanderley (2000), even with the industrialization and urbanization processes, besides technologies being applied to agriculture, standardization does not occur in the society, the particularities of the spaces remain, such as the family traditions which individuals affiliate to.

A relevant point is that both the rural and the urban areas undergo progressive modifications in their structures. Under that perspective, the geographical environment, a creation of society, is subject to constant alterations in its morphology. The rural space should not be thought of as something rustic or isolated, even if some rural areas are (GOMES et al., 2016); this is merely a general profile identified with these environments. We should think of an environment of new ruralities always under reconstruction (WANDERLEY, 2000; FAVARETO, 2007). 


\section{Environmental Psychology and Bioecological Model of Human Development}

One of the major characteristics of Environmental Psychology is interdisciplinarity (GÜNTHER, 2005), allowing different areas to converse, such as the field of public policies and the Bronfenbrenner (2011) Bioecological Approach to Human Development. Environmental Psychology brings as a contribution the bidirectional vision of the personenvironment relationship. According to Günther (2003, 2005), there is a reciprocal relationship between the persons and the physical space surrounding them; the actions of one modifies the other, in a feedback process. It is not solely the environment that modifies individuals, but the latter can exert changes on their environment, which mainly occurs when the environment fails to meet the objectives and needs of the 'people there inserted (MELO, 1991).

Even though the human being is constantly relating with the environment and is able to modify it, there are certain human needs that are not solely met by the human-environment relationship. According to the Bioecological Approach to Human Development by Bronfenbrenner (2011), human development results from a dynamic interaction of the individuals with the environmental contexts surrounding them, in a direct relationship with the individuals' psychosocial well-being. The analysis places as essential the observation of a set of interactions of human beings and their environment, with the time (from the individual time to historical time) and in their proximal processes.

Bronfenbrenner and Morris (1998) e Bronfenbrenner $(1999,2011)$ divide their investigation into four major elements: Person, Process, Context and Time (PPCT). The person has individual characteristics, with all of its demands, dispositions and resources: 1) resources are considered all the biopsychological characteristics of the person, physical, cognitive and affective aspects; 2 ) dispositions are all the contingencies and interests that may stimulate or discourage the person to continue his/her development process, and 3) demands are the encouraging aspects of the participation in their processes.

Process, which regards proximal processes, may be related to all the proximal interactions persons experience in their life with other persons, objects and symbols that directly interfere with their development. This interaction occurs in nearby environments and, for it to occur, standards need to be established for extended periods of time. As a warning, Bronfenbrenner (1999) stresses that this element is easily mistaken with the context, yet it has peculiarities, especially related to the interactions established in it and in the characteristics of the persons that interact.

Context is analyzed from all the environmental influences in the person's development. It is subdivided into microsystem, mesosystem, exosystem and macrosystem. Microsystem are all the environments in which the proximal processes occur, those directly related to the person; in the case of the Rural Area inhabitant, we can consider the natural environment daily frequented by the persons, their family, among others. The mesosystem concerns the direct relationship between these microsystems. In the rural area, an example is the relationship of the work environment with the home. The exosystem is constituted by the set of social institutions that do not directly contain the persons, but which may affect the microsystem and the mesosystem in which they are 
inserted, for example, the transportation between the rural area and the urban area, the rural schools. Bronfenbrenner (2011) specifies the macrosystem as formed by the cultural elements, that is, beliefs, values and behavior standards that influence the existence of the group in which the person is inserted. It is in this analysis system that public policies and economic issues fit.

Another aspect of the Bioecological Model of Human Development is Time. Bronfenbrenner and Morris (1998) and Bronfenbrenner $(1999,2011)$ specify the need for the chronosystem approach, subdivided into: microtime, mesotime and macrotime. The first regards the different durations of the proximal processes episodes. Mesotime regards the periodicity of these episodes and macrotime concerns the events of society in general, historical and social, which affect and are affected by the development of the persons over the course of their lives.

As from Bronfenbrenner (2011), the implementation of public policies is considered to have as an effect the modification of both the environment and of the person. The development and planning of public policies and social programs is of unique importance in the task of minimizing the possible negative influences of an unfavorable environmental context in human development, once the favorable changes in the environment may generate, according to the bidirectional logic, not only well-being to the inhabitants of the Rural Area, but also favor their healthy development (BRONFENBRENNER, 2011.).

According to Turner III (2010), it is of crucial importance for studies on human phenomena that there is ecological insertion for better understanding what is studied and the very individuals in their contexts. It is listening to the human beings in their environment to capture the point of view and their experience in the fullest possible way. Hence, for conducting this research, interviews were made with the inhabitants of the rural area in their own life contexts.

\section{Methodology of investigation}

The methodology of investigation was founded on the González-Rey Qualitative Epistemology, deriving from historical social psychology, the focus of which is the subjectivity of the participant and the complexity, conversing with two pillars of transdisciplinarity (PINTO; de PAULA, 2018). Two methods were used for collecting information: interviews based on the life history method and a documentary investigation (PIMENTEL, 2001) into the data on the public policies for the Rural Area surveyed in the municipality town hall. From the Bioecological Approach (BRONFENBRENNER, 2011) perspective, the investigation focused on the relationship between the Persons and their Contexts and the influence of public policies on them.

\section{Context of investigation}

The process known as rural exodus had already started in the country, which culminated in a large populational contingent moving to the Brazilian cities. In the last great census of 2010, the Brazilian population in the urban areas already exceeded $84 \%$ (IBGE, 2010), a process that can be verified in the municipality of São João del-Rei, place of the 
study. The data of the analysis visualized in Box 1 allows inferring that the population of the rural area has fallen at each great census conducted.

\section{Box 1 - Evolution of the São João del-Rei population-} al framework, in the last five great censuses.

\begin{tabular}{|c|c|c|}
\hline São João del-Rei - Census & Urban & Rural \\
\hline 1970 & 47,138 & 8,092 \\
\hline 1980 & 56,325 & 8,328 \\
\hline 1990 & 66,700 & 6,047 \\
\hline 2000 & 73,785 & 4,831 \\
\hline 2010 & 79,857 & 4,612 \\
\hline
\end{tabular}

Source: Statistical Yearbook of São João Del-Rei 1999 and 2015.

The history of the municipality of São João del-Rei dates back to the XVIII century, when Antônio Garcia da Cunha started the gold extraction process, which originated the arraial (settlement) Novo Pilar, currently the São João municipality. (LOBO; TÉSSIA, 2012). In the beginning, São João del-Rei took on an essentially agricultural characteristic.

The municipality has a total area of $1,464 \mathrm{~km}^{2}$, divided into six subdivisions and the headquarter. The districts are Emboabas, Rio das Mortes, São Gonçalo do Amarante, São Sebastião da Vitória and São Miguel do Cajuru. According to IBGE (2010), these six subdivisions are divided into urban and rural areas. In them, six communities considered rural in the region de São João del-Rei were investigated; they are identified in Figure 1: Barreiro, Felizardo, Colônia do Bengo, Zueira, Recondengo and Rio das Mortes. These rural spaces are spatially distributed in relation with the main town, São João del-Rei. Some are located only 10 kilometers away and others are 40 kilometers away. Three of them, close to São João, are known for their Italian colonization (Bengo, Recondendo and Felizardo). 
Figure 1 - Location of the rural communities of São João del-Rei.

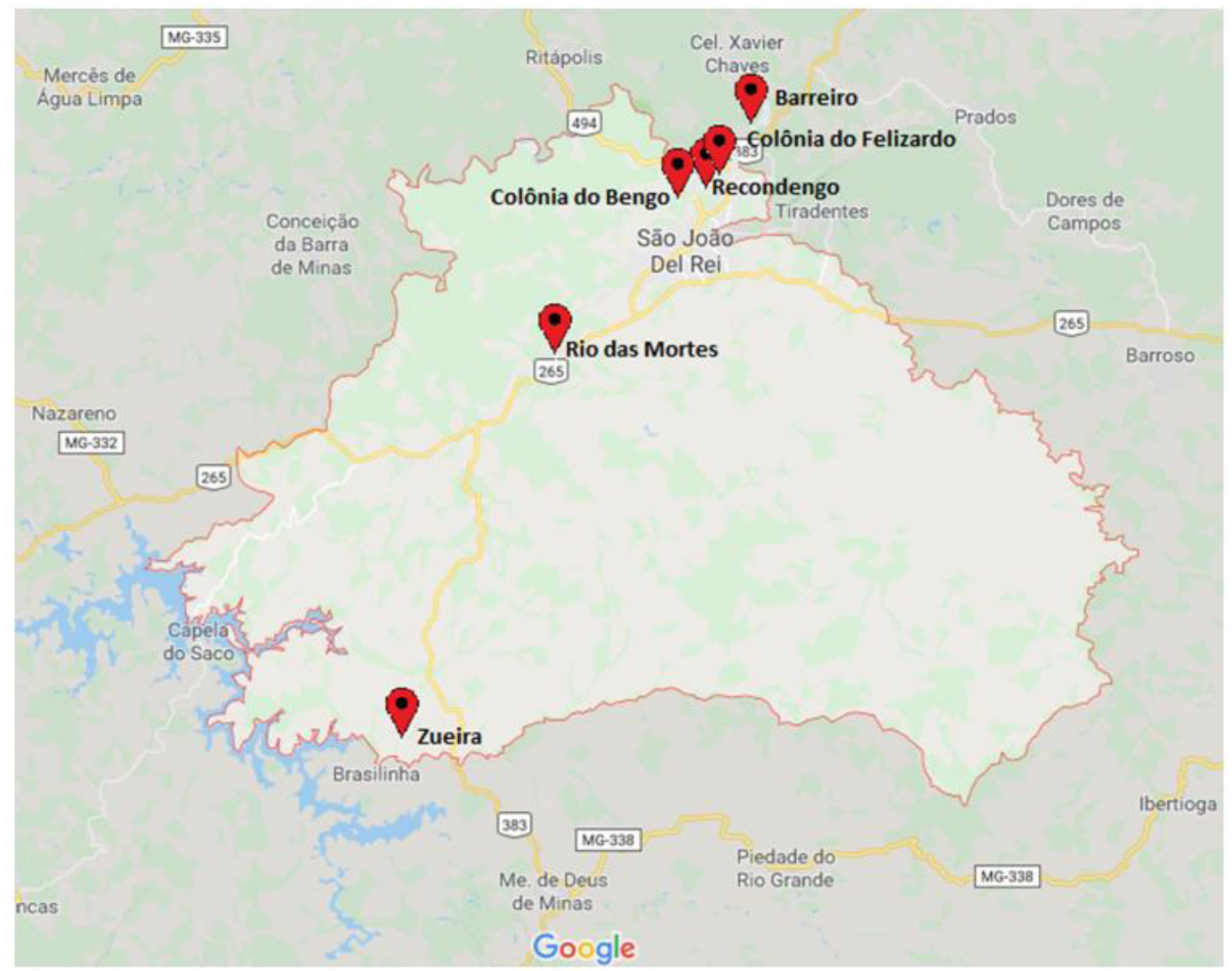

Source: Authors' files, developed in Google Maps, 2019.

\section{The participants}

The first step was contacting the Municipal Government and the City Council for collecting the documentary data, which allowed for a general idea of the situation of the relationship of the public management with the inhabitants of those areas.

At a second moment, we selected key informers of the history of the region in each settlement investigated, indicated by the very inhabitants of each community. The informers were invited and participated according to their acceptance and availability. 11 persons participated, six women and five men, from six communities considered rural in the region of São João del-Rei. The youngest was 17 years old, and the oldest, 80 years old. In each settlement, two persons were interviewed: two women in Barreiro (Giovana and Neide), two in Felizardo (Naiara and Soraia), two men in the Bengo settlement (João and Ezequiel), a man and a woman in Zueira (Míriam and Leandro), a man and a woman in Recondengo (Ronaldo and Ondina), being Rio das Mortes the only place in which a single interview was made, with a man (Fábio). All the names presented are fictitious 
aiming to protect the participants' identities.

\section{Details of the investigation tools}

The interviews made were open and considered the knowledge building process in a non-linear manner, yet interpretive, in an inter-relationship between the participant's and the researcher's subjectivity, according to Qualitative Epistemology (GONZÁLES-REY; SILVA, 2005). We sought the construction of an interpretation of the meanings attributed by the participants regarding the theme proposed, with an anthropo-sociological view, in a dialogical communication and with an understanding of the human being in different social and physical spaces, here considered development contexts (BRONFENBRENNER; MORRIS, 1998; BRONFENBRENNER, 1999, 2011).

The proposal unfolded from the central theme, which was the history of the participant and that of the region, considering the ongoing public policies, as well as their individual relationship with the surrounding environment. The interviewees could speak freely and approach different subjects concerning their experience in the region.

\section{Data collection}

The interviews occurred after scheduling appointments with the researchers and the participants, in a place indicated by the latter. According to the participant's consent, the interviews were recorded and, after transcribed, were again presented to those interested in certifying their content. At that moment, a new collection was made aiming to obtain complementary information.

The research was approved by the Ethics Committee - CAAE 54709215.5.0000.5151 and all the precautions were taken for the research ethics according to RESOLUTION $\mathrm{N}^{\mathrm{o}}$ 466, of DECEMBER 12, 2012 (BRAZIL, 2012), which included signing the informed consent form.

\section{Analysis of the information}

The information was analyzed as from the Qualitative Epistemology (GONZÁLEZREY; SILVA, 2005): 1) Pre-analysis: the interviews were read and reread until their content and their meaning were understood by the researcher; 2) Identification of indicators: subjectively conducted from the pre-analysis moment, highlighting the most frequent sentences and keywords and contextualized in the reading of the interviews, which stood out in the researcher's subjectivity; 3) Construction of the areas of meaning: areas of results synthesis; in these, the indicators were grouped into areas expressing their meanings, synthesizing the indicators found; 4) Theoretical construction: conducted as from the areas of meaning and from the relationship of the synthesis obtained from the preexisting theory and the investigator's analysis.

\section{Results}

We observed that no documentary data were found on the rural area region of the municipality; there are no maps and the policies for the region are not an integral part 
of the Master Plan. The results presented regards the interviews made (Box 2), from the areas of meaning found and from their indicators. The sections pointed out as indicators and their verbalizations are identified by the fictitious names given to the participants.

\section{Box 2 - Areas of meaning and indicators found in the interviews}

\begin{tabular}{|c|c|c|}
\hline $\begin{array}{l}\text { Areas of } \\
\text { meaning }\end{array}$ & Indicators & Verbalizations \\
\hline \multirow[t]{8}{*}{$\begin{array}{l}\text { About "being } \\
\text { rural" }\end{array}$} & Distances & $\begin{array}{l}{[\ldots] \text { the closer you get to the town, the less Rural the area is [...] (João). }} \\
{[\ldots] \text { the access to go to the place is hard. (Neide) }} \\
{[\ldots] 44 \text { or } 45 \text { kilometers to the center of São João. (Leandro) }} \\
{[\ldots] \text { the neighbor is five hundred meters away [...] (Naiara) }}\end{array}$ \\
\hline & Communication & $\begin{array}{l}{[\ldots] \text { is very backward [post office services]. We depend on the Giarola }} \\
\text { Post Office, there near the settlement [...] (Giovana) } \\
\text { An antenna very far, to throw to us here. Keeps falling, then there's no } \\
\text { competition (Ezequiel) }\end{array}$ \\
\hline & External view & $\begin{array}{l}\text { The thing is that most people think of the rural area as backward people } \\
\text { [...] (Naiara) }\end{array}$ \\
\hline & Community & $\begin{array}{l}\text { It was the people here that planted the grass, we go doing work together, } \\
\text { y' know? (Neide) } \\
\text { [...] my mom had a house over there; opposite my uncle's house was our } \\
\text { house [...] Everybody family . (João) } \\
\text { [...] some houses that keep growing. But they're few, but is of the family, } \\
\text { one got married, just like me. (Ezequiel) } \\
{[\ldots] \text { today nobody wants to get together. But when everybody is together }} \\
\text { is good, makes good parties [...] (Leandro) } \\
\text { [...] What I don't plant and my neighbor does and we swap and there's } \\
\text { always this relationship of living well together. (Naiara) }\end{array}$ \\
\hline & $\begin{array}{l}\text { Knowledge from } \\
\text { generation to gen- } \\
\text { eration }\end{array}$ & $\begin{array}{l}{[\ldots] \text { knowledge that comes from generation to generation and that today }} \\
\text { is has little value }[\ldots] \text { (Naiara) } \\
\text { Then started to teach the kids to milk the cow }[\ldots] \text { (Míriam) }\end{array}$ \\
\hline & $\begin{array}{l}\text { Existence of live- } \\
\text { stock and planta- } \\
\text { tions }\end{array}$ & $\begin{array}{l}\text { [rural area] is you havin' a cow, get some milk (João). } \\
{[\ldots] \text { for those who want to live from the land [...] (Naiara) }} \\
\text { Ahh, all that I plant, do, I sell [...] (Ondina) } \\
\text { There's plantations that supply São João, they plant yam, deal with cattle, } \\
\text { milk. (Giovana) } \\
\text { Yeah, there's orchard, I deal with the chicken. (Leandro) }\end{array}$ \\
\hline & It is not rural & $\begin{array}{l}{[\ldots] \text { I don't consider, ... I think it is a place to plant and almost at the }} \\
\text { same time it's turning into a town neighborhood. (Ondina) } \\
\text { Not today [is rural]. [...] there are places much worse than here to call } \\
\text { rural area (Neide) }\end{array}$ \\
\hline & It is dying out & $\begin{array}{l}\text { Rural area is really dyin' out... (João) } \\
{[\ldots] \text { if you look today not even this here is rural almost, right? (Ondina) }}\end{array}$ \\
\hline
\end{tabular}




\begin{tabular}{|c|c|c|}
\hline \multirow[t]{4}{*}{ Existing policies } & Government support & $\begin{array}{l}{[\ldots] \text { we're part of that program of family farming }[\ldots] \text { (Neide) }} \\
{[\ldots] \text { to a festivity it gives support. (Leandro) }} \\
{[. .] \text { I supply for two state [schools] [...] (Ondina) }}\end{array}$ \\
\hline & Garbage collection & 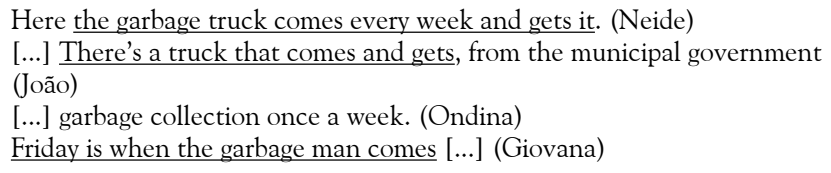 \\
\hline & Public transportation & 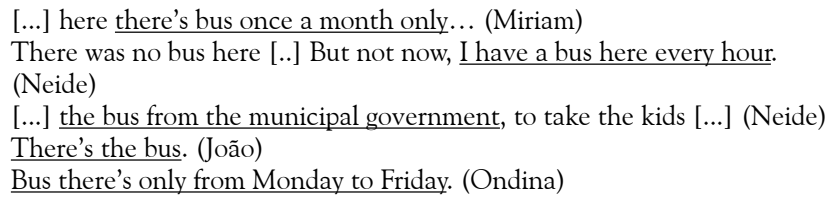 \\
\hline & Road improvement & $\begin{array}{l}\text { The road a part, [...] you could not get.... when it rained you had to go out } \\
\text { shoes in hand. (Neide) } \\
{[\ldots . .] \text { there was one time the road crumbled all down, we had to tie the }} \\
\text { trucks all [...] (Leandro) } \\
\text { The people there gets a hard time with all that dust, the truck passes very } \\
\text { close, got it? (Miriam) }\end{array}$ \\
\hline \multirow[t]{5}{*}{$\begin{array}{l}\text { Necessary poli- } \\
\text { cies }\end{array}$} & $\begin{array}{l}\text { Water supply and } \\
\text { sanitation }\end{array}$ & $\begin{array}{l}{[\ldots] \text { what we fight more for }[\ldots] \text { is water. (Neide) }} \\
{[\ldots . .] \text { there's cesspool, no treated sewage no nothing, and water, in the }} \\
\text { case, is cistern or water spring [...] (João) } \\
{[\ldots] \text { we make a hole and make the cesspool. (Ondina) }} \\
\text { There it is still cesspool [...] (Giovana). } \\
\text { There's no sewage system, here, in the case, the houses all use the cess- } \\
\text { pool system, there's no water from the street (supply system), [...] gotta } \\
\text { dig a well, that's it. (Ezequiel) }\end{array}$ \\
\hline & Lighting & Put up public lighting. (Ezequiel) \\
\hline & Leisure and tourism & $\begin{array}{l}\text { This thing of tourism, I think it gives that identity }[\ldots] \text { (Giovana) } \\
\text { Here there had to be leisure, for the old guys, for the kids [...] (Soraia) } \\
{[\ldots . .] \text { we already asked for a project to the municipal government for them }} \\
\text { to put, what do you call it? These [work out] equipment, }[\ldots] \text {, we're fight- } \\
\text { ing to see that we get it... (Neide) }\end{array}$ \\
\hline & & $\begin{array}{l}\text { Here needed a doctor, pediatrician, at least every } 15 \text { days [...] (Miriam) } \\
\text { There's the doctor and the exams we have to do is usually in Resende } \\
\text { Costa or Prados. (Neide) } \\
\text { At least one health center to care for the community [...] (João) } \\
\text { Health that we don't have here. (Leandro) }\end{array}$ \\
\hline & Need of road & $\begin{array}{l}{[\ldots] \text { that pavement there in the street, hell of a dust... Road that if it }} \\
\text { rains, there's no getting out [..] (Leandro) } \\
{[\ldots . .] \text { a large part of the estate products is perishable, with that bad road, }} \\
\text { tends to "rot" [...] (Ronaldo) } \\
\text { This road of ours is bad. 'cause you havin' a good path, }[\ldots . .] \text { you can even } \\
\text { sell and take (Ondina) } \\
{[\ldots] \text { if the road is bad the bus starts to break down. (Ezequiel) }} \\
{[\ldots] \text { the greatest need for the subdivision today is the road, [...] (Naiara) }} \\
\text { Even the means of transport is difficult. (Neide) } \\
\text { [the road] now in the rainy period gets even more rotten [...] (Giovana) }\end{array}$ \\
\hline
\end{tabular}

Source: Authors' file, data from the interviews. 


\section{Discussion}

The discussion is based on the information described in Box 2; the areas of meaning are highlighted in bold and the indicators, underlined. To understand the definition of rural by the inhabitants, in the area of meaning About being rural, we consider what the inhabitants of those regions understand as "being rural". Noting that, politically, this delimitation is an attribution of the municipal government (BRAZIL, 1938) from different social and economic aspects, an attribution of the macrosystem, conducted at a certain historical period (BRONFENBRENNER; MORRIS, 1998; BRONFENBRENNER, 1999, 2011), but that influences the inhabitants' lives of the rural area and their experiences in the micro, meso and exosystems, without considering the differences found in each of the contexts studied. In this sense, more than describing what is rural, this work considers it necessary to identify its inhabitants' view on what rural is.

In the interviews made, the inhabitants were asked if they considered the region rural. We surveyed local characteristics the inhabitants consider relevant for the environment to be classified as such, respecting the man-environment relationship perspective (GÜNTHER, 2005). Therefore, of the 11 interviewees, only two did not consider their region rural (It is not rural); a woman living in Barreiro and the other in Recondengo.

The inhabitants pointed out as relevant for classifying the environment as rural, the distance from the settlement to the city (Distances), and the distance between their own houses. The economic issue and the typical uses (Knowledge from generation to generation) of the rural area were mentioned as differentiating between rural and urban, besides the Existence of livestock and plantations, as highlighted by Leandro. The characteristics reported come close to the definition of Rural Area by the Commission of the European Communities (CEC) (GOMES, 2013).

As stated, two inhabitants (Neide and Ondina), do not consider the place they live in rural (It is not rural) and affirm that the rurality of a place is the facility of accessing it, the means of Communication available and Transportation. This view comes close to the characteristics indicated by the other participants when considering their region rural. This shows that, as highlighted by Gomes (2013), despite the innumerous modifications made to the rural environment, the still prevailing thought is that of rural as an isolated and rustic place, issues connected to the possibilities found in the exosystem (BRONFENBRENNER; MORRIS, 1998; BRONFENBRENNER, 1999, 2011) that affect the individuals' lives and their perception about the space they live in. What makes João and Ondina affirm that the rural area is dying out, or may be considered the reference by Souza and Brandenburg (2010, p. 53) about the "metropolitan" rural.

Naiara, living in Felizardo, made it a point to stress a negative view existing about the rural areas and about their inhabitants (External view). The discourse exposes the position of several individuals that still see the rural area as backward, without knowledge and lacking resources, stigmatizing this reality. Consequently, the social stigmas are eventually introjected and reproduced by some inhabitants, which is confirmed in Neide's discourse, as she does not consider her region rural, and argues that there are worse places. This conjuncture brings to light the direct influence of the macrosystem on 
the individuals' development. In this case, the combination of cultural elements, beliefs, negative values constructed socially-historically about what a rural area (macrosystem) is eventually influences the very manner in which the inhabitants see it and their collective existence in this environment (microsystem). The Community seems to be identified as one of the major characteristics of life in the rural area. As states Bronfenbrenner (2011), social identification marks are created for certain cultures or subcultures.

The different forms of characterizing Rural Area by the global entities concerned with the issue, exposed by Gomes (2013), appear in the discourses of the Rural Areas inhabitants of the municipality of São João del-Rei. The inhabitants' ideas corroborate Gomes's (2011) thought, who highlights that rural, despite having technological development characteristics, still keeps its own traditions, lifestyles and connections, which we consider present especially in the micro and mesosystems.

Faced with the Existing policies area of meaning, studies conducted by SEBRAEMG (2008) on the theme make it clear that, in their majority, rural public policies seek to meet the economic interests of agricultural production. According to those data, the Rural Area public policies do not take into account the populational contingent and its peculiarities as regards social needs. This is made more evident in the discourses of the inhabitants interviewed.

As a public service available, in common, all the places visited have Garbage collection at least once a week. In two of the interviews, the supply of free transportation of children to their respective schools was mentioned. Public transportation is provided in nine of the eleven communities researched, except for Recondengo and for the Zueira community, where it occurs irregularly and insufficiently, as reported by Míriam. Neide and Míriam mentioned Road Improvement, yet this was seen as insufficient, as demonstrated in the Necessary policies area of meaning.

From the Government support indicator, in the interview made with Neide, who lives in Barreiro, we verified the existence of a public policy directed to family farming. She mentions cultivating kale, broccoli and other vegetables in her estate; Leandro reports that the municipal government supports events in the region and Ondina, a Recondengo dweller, mentions a partnership for supplying state schools. However, those were the only positive actions of the municipal government mentioned by the 11 interviewees.

Public policies, for having a governmental character, eventually privilege certain social-economic sectors. This is pointed out by authors such as Ortega and Fonseca (2009), Pereira (2010), Souza and Brandenburg (2010) and Silva (2012), when stating that the main public policies directed to the rural areas in Brazil come from the federal spheres and are directed to meet mainly issues regarding funds for plantations and livestock breeding, leaving aside the needs of the populations residing in those places. It can be observed that issues such as human development are not preponderant in the design of public policies, as advocated by Bronfenbrenner (2011). Public policies belong to the macrosystem field, but they influence the persons in their micro, meso and exosystems. For the author, positive changes in the environment may directly influence the healthy development of human beings. One of the ways for these changes to occur is promoting 
solid and relevant public policies to the population. For these policies to be really effective in the context studied, it is necessary to listen to the inhabitants of those regions, who have demands and needs characteristic of their environmental context, mentioned in the Necessary policies area of meaning.

Four of the six communities visited present several environmental similarities due to their proximity. Nevertheless, there are characteristics differencing them as communities. The Bengo, Felizardo, Barreiro and Rio das Mortes settlements are closer to the center of the town, up to 12 kilometers away. Consequently, public policies show to be more active in those four communities, e.g., with more constant public transportation and more frequent garbage collection. However, the communities farther away from the urban area, Recondengo and Zueira settlements, do not have the same facilities, have scarce or lack the services aforementioned. Only Rio das Mortes counts on a school in the very community.

In none of the communities visited is there water or sewage system (Water supply and sanitation). The water supply is provided by water springs existing in the regions. They also lack sewage treatment and use the cesspool system for collecting it.

The strongest complaint by the inhabitants, mentioned in nine of the eleven interviews, regarded the condition of the roads (Need of road), mainly in the regions in which agriculture is the major survival means and the road is characterized as the only path for the production outflow. Inhabitant Ronaldo reports that the consequences of the problems caused by the quality of the road regard the potholes resulting from the rainy season and from the declivity of the place.

This problem hinders the transportation of the products, which are largely perishable and, with a bad road, they tend to "rot" (Ronaldo), causing the consumer market not to accept them. The Zueira interviewee, Míriam, criticizes the quality of the road, "The people there gets a hard time with all that dust, the truck passes very close, got it? Here I'm quite far, though lots of dust come this way". Living in the same community, Leandro questions the quality of the road, "Here's everything, this paving there in the street, hell of a lot of dust... Road that if it rains, there's no getting out; were it raining here, you'd no way get here".

The inhabitants report that the concern with violence is minimal, except for Rio das Mortes, where they say there are high criminality rates. Violence is reported mainly in the communities with asphalt paving; this was mentioned as a source for the increase of violence in the place. From these statements, one can observe the influence exerted by the environment in constant changes on the inhabitants' values and subjectivities, on the man-environment inter-relationship (GÜNTHER, 2003, 2005).

Another concern is the health (Public health) issue. Giovana says that the inhabitants' health is affected by the dust, due to the lack of maintenance in the roads, relating the health problem with the asphalt. This takes us directly back to the Bronfenbrenner's (2011) systems, in which the lack of governmental actions, which represent the exosystem, directly influences the rural inhabitants' health. The interviewees emphasize the lack of doctors in the region. 
As a third point in common, we have the Communication issue, whose lack or restricted access may influence aspects in the micro, meso and exosystems, and was indicated as one of the characteristics of the Being rural area of meaning. Mobile phone, landline telephone, internet and even post office services were mentioned as necessary aspects for improvement. Living in Bengo and Recondengo, Ezequiel and Ronaldo point out that those services are not provided or are insufficient due to the populational contingent of the place they live in being small. Fábio reports how difficult it was to obtain landline telephones in their region, and resulted from the inhabitants' articulation. Only Ezequiel pointed out the lack of public lighting as a problem.

The interviewees also mentioned the need of developing public policies directed to increasing self-esteem and the quality of life in the regions, identified as Leisure and tourism, such as investing in tourism and in actions directed to those populations' leisure. Giovana points out: "This thing of tourism, I think it gives that identity (...) I guess it'd give more of that air of asset things".

From the inhabitants' discourses, the public policies are perceived to be able to alter the conditions of life in the rural environment, increasing or decreasing the agricultural production capacity, the access to technologies and to information, modifying the physical structures of the place, facilitating or hindering the lives of the persons living there and, with this, the very persons. Th interviews demonstrated that it is important for the public bodies to make resources available for creating public policies that minimize the differences between urban and rural, and meet the specificities of the rural population (GEHLEN, 2004), considering data closer to the reality of those places (FAVARETO; ABRAMOVAY, 2009).

\section{Conclusions}

The interviews allowed identifying a lack of action by the public sectors as regards the public policies directed to the Rural Area of São João del-Rei, which was confirmed by the lack of data in the Municipal Government and in the Town Council. The inhabitants show to be concerned with the lack of action by the municipal government, concurrently with demonstrating their awareness of the importance of governmental actions to be developed in their communities.

The major need found was the lack of an adequate transportation infrastructure, especially related to the quality of the roads, which influence both their day-to-day and the outflow of the produce. This lack of attention by the municipal public bodies to maintain the roads of urban-rural connection causes considerable losses to those growing agricultural products, who mostly depend on these roads to deliver their products. Furthermore, the roads raise dense dust clouds, harming the inhabitants' health.

As regards the concept of Rural Area, we emphasize that most of the participants consider the region they live in as rural and identify themselves with the local lifestyle. Nevertheless, the very inhabitants were perceived to describe their regions with a somewhat undermined prestige. It can be affirmed that the social devaluation concerning the 
rural area, present in the culture and in the social values (macrosystem) reflects on the way these populations live, articulate and see the rural area (microsystem) (BRONFENBRENNER, 2011).

According to Bronfenbrenner (2011), even though the macrosystem somewhat influences collective thought, in some cases, standing out are the characteristics of the Persons that seek motivations and personal meanings to create their own experience for their healthy development and self-esteem. The need of valorizing traditions and rural area culture, as well as the individuals living there is considered. As states Bronfenbrenner, the more opportunities are given by governments for promoting diversified activities for the people, such as basic conditions for survival, the more their development process is stimulated.

It is thus made necessary to develop public policies that are consistent with the local reality, directed to strengthening the region inhabitants' self-esteem and identity, which could be done, according to the inhabitants, by strengthening the local tourism and leisure in the region. Meeting the need for more significant actions by the public bodies in the rural area, providing the necessary subsidies, such as sewage, better access infrastructure, accessible and quality health, so that human development is stimulated and consolidated in these regions, would thus facilitate the inhabitants' lives. Lastly, public policies can be devised, besides a greater interaction with the regulations related to the land and to the environment, aiming to contribute for these inhabitants to develop new relationships with the land and its spaces, such as those related to family farming, in their relationship with agroecology and food sovereignty.

\section{Acknowledgements}

To the Fundação de Amparo a Research de Minas Gerais (FAPEMIG - The State of Minas Gerais Research Foundation), which financed the project and to the inhabitants who contributed by sharing their narrative.

\section{Referências}

BRASIL. Decreto-Lei no 311, de 2 de março de 1938. Dispõe sobre a divisão territorial do país, e dá outras providências. Disponível em http://www2.camara.leg.br/legin/fed/declei/1930-1939/ decreto-lei-311-2-marco-1938-351501-publicacaooriginal-1-pe.html. Acesso em 30 mai. 2018.

BRASIL. Ministério da Saúde. Conselho Nacional de Saúde. Resolução no 466, de 12 de dezembro de 2012. Aprova as diretrizes e normas regulamentadoras de pesquisas envolvendo seres humanos. Disponível em: <http://bvsms.saude.gov.br/bvs/saudelegis/cns/2013/ res0466_12_12_2012.html>. Acesso em 10 jun. 2019. 
BRONFENBRENNER, U. Environments in developmental perspective: Theoretical and operational models. In: FRIEDMAN, S. L.; WACHS, T. D. (Eds). Measuring environment across the life span: Emerging methods and concepts. Washington, DC: American Psychological Association, 1999. p. 3-28.

BRONFENBRENNER, U. Bioecologia do desenvolvimento humano: tornando os seres humanos mais humanos. Porto Alegre: Artmed Editora, 2011.

BRONFENBRENNER, U.; MORRIS, P. A. The ecology of developmental processes. In: DAMON, W.; SIGEL, I. E.; RENNINGER, K. A. (Eds). Handbook of child psychology. New York: John Wiley \& Sons, 1998. p. 993-1027.

FAVARETO, A. D. S. A Longa evolução da relação rural-urbano: Para além de uma abordagem normativa Do Desenvolvimento Rural. Ruris, Campinas, v. 1, n. 1, p. 157-92, 2007.

FAVARETO, A. D. S.; ABRAMOVAY, R. Surpreendente desempenho do Brasil rural nos anos 1990. Documento de trabajo/Programa Dinámicas Territoriales Rurales. RIMISP-Centro Latinoamericano para el Desarrollo Rural, no. 32, 2009.

GOMES, I. O espaço rural em questão: o caso dos municípios rurais de Minas Gerais. Revista Eletrônica da Associação dos Geógrafos Brasileiros Seção Três Lagoas, v. 1, n. 13, p. 155-178, 2011.

GOMES, I. O que é rural? Contribuições ao debate. Boletim de Geografia, Maringá, v. 31, n. 3, p. 81-95, 2013.

GOMES, I. et al. Comunidades Rurais (mas nem tanto): proposta de definição de critérios para diferenciação rural-urbana. Revista Geografias, Belo Horizonte, v. 1, n. 21, p. 122-137, 2016.

GONZÁLEZ-REY, F. L. G.; SILVA, M. A. F. Pesquisa qualitativa e subjetividade: os processos de construção da informação. São Paulo: Cengage Learning, 2005.

GÜNTHER, H. A Psicologia Ambiental no campo interdisciplinar de conhecimento. Psicologia USP, São Paulo, v. 16, n. 1-2, p. 179-183, 2005.

GÜNTHER, H. Mobilidade e affordance como cerne dos estudos pessoaambiente. Estudos de Psicologia, Natal, v. 8, n. 2, p. 273-280, 2003.

GEHLEN, I. Políticas públicas e desenvolvimento social rural. São Paulo em Perspectiva, São Paulo, v. 18, n. 2, p. 95-103, 2004.

INSTITUTO BRASILEIRO DE GEOGRAFIA E ESTATÍSTICA (IBGE). Censo de 2010. Disponível em: < https://censo2010.ibge.gov.br/noticiascenso?

view $=$ noticia $\& i d=3 \&$ idnoticia $=1766 \&$ busca $=\& t=$ censo-2010 - populacao-brasilde $-190-732$ 694-pessoas>. Acesso em: 30 abr. 2018.

KAGEYAMA, A. Desenvolvimento rural: conceito e medida. Cadernos de 
Ciência \& Tecnologia, Brasília, v. 21, n. 3, p. 379-408, 2004a.

KAGEYAMA, A. Mudanças no trabalho rural no Brasil, 1992-2002. Agricultura em São Paulo, São Paulo, v. 51, n. 2, p. 71-84, 2004 b.

LEITÃO, A. L. E. et al. Política Pública para a Agricultura Familiar: o Programa Nacional de Desenvolvimento Sustentável dos Territórios Rurais (Proinf) no Território Caparaó-ES. Rio de Janeiro: UFRRJ, 172 p. 2009.

LOBO, C.; TÉSSIA, J. Dinâmica migratória na região de influência de São João del-Rei: os fluxos e a organização do espaço regional. Revista Paranaense de Desenvolvimento-RPD, Curitiba, n. 121, p. 149-165, 2012.

MELO, R. G. C. de. Psicologia ambiental: uma nova abordagem da psicologia. Psicologia USP, São Paulo, v. 2, n. 1-2, p. 85-103, 1991.

ORTEGA, A. C.; FONSECA, S. G. Políticas de Educação para o Mundo Rural Brasileiro: Entre a Universalização e a Diferenciação dos Conteúdos. Ensino em Re-Vista, Uberlândia, n. 12, v. 1, p. 99-106, 2004.

PEREIRA, M. F. Política agrícola brasileira e a pequena produção familiar: heranças históricas e seus efeitos no presente. Revista Brasileira de Gestão e Desenvolvimento Regional, Taubaté, v. 6, n. 3, p. 287-311, 2010.

PIMENTEL, A. O método da análise documental: seu uso numa pesquisa historiográfica. Cadernos de Pesquisa, São Paulo, n. 114, p. 179-195, 2001.

PINTO, J. F; de PAULA, A. P. P. Contribuições da epistemologia qualitativa de González Rey para estudos Transdisciplinares. Psicologia \& Sociedade, Belo Horizonte, v. 30, p. e166100, 2018.

RAMOS, B. S. A inserção da agricultura familiar nas políticas públicas de desenvolvimento territorial rural no brasil: um olhar a partir do governo de Fernando Henrique Cardoso e Lula. In: VII JORNADA INTERNACIONAL DE POLÍTICAS PÚBLICAS, 25 a 28 de agosto de 2015. Anais... Cidade Universitária da UFMA, São Luiz/Maranhão, Brasil.

SEBRAE MG (2008). Políticas Públicas Conceitos e Práticas. Disponível em: <http:// www.mp.ce.gov.br/nespeciais/promulher/manuais/MANUAL\%20DE\%20POLITICAS\%20 P\%C3\%9ABLICAS.pdf >. Acesso em: 28 mai. 2018.

SILVA, R. N. (2012). Políticas públicas de desenvolvimento rural no Brasil: o caso do Programa Nacional de Fortalecimento da Agricultura Familiar (PRONAF). XXI ENCONTRO NACIO. NAL DE GEOGRAFIA AGRÁRIA. Anais... Uberlândia - MG, 15 a 19 de outubro de 2012.

SOUZA, O. T.; BRANDENBURG, A. A quem pertence o espaço rural? As mudanças na relação sociedade/natureza e o surgimento da dimensão pública do espaço rural. Ambiente $\mathbb{\&}$ Sociedade, São Paulo, v. 13, n. 1, p. 51-64, 2010. 
TURNER III, D. W. Qualitative interview design: A practical guide for novice investigators. The qualitative report, Flórida, v. 15, n. 3, p. 754-760, 2010.

WANDERLEY, M. N. B. A emergência de uma nova ruralidade nas sociedades modernas avançadas-O "rural" como espaço singular e ator coletivo. Estudos sociedade e agricultura, Rio de Janeiro, v. 15, p. 87-145, 2000. 
Larissa Medeiros Marinho dos Santos

ఐ larissa@ufsj.edu.br

ORCiD: https://orcid.org/0000-0003-4906-4163
Submitted on: 25/06/2018

Accepted on: 22/05/2020

2020;23:e01633

\section{Johnny da Costa Barbosa}

$\square$ johnny.contato@live.com

ORCiD: https://orcid.org/0000-0002-7681-3804

Rodrigo Meireles dos Santos

$\square$ rodmeireles3110@gmail.com

ORCiD: https://orcid.org/0000-0003-3921-3938

\section{Anna Beatriz Ribeiro Paiva Netto}

$\square$ annabia_n@hotmail.com

ORCiD: https://orcid.org/0000-0003-1276-9231

How to cite: SANTOS, L. M. M. et al. Public Policies in the Rural Area of São João del-Rei: An inhabitants' view. Ambiente \& Sociedade. São Paulo, v. 23, p. 1-19, 2020. 


\title{
Políticas Públicas na Zona Rural de São João del-Rei: Uma visão de seus moradores
}

\author{
Larissa Medeiros Marinho dos Santos \\ Johnny da Costa Barbosa \\ Rodrigo Meireles dos Santos \\ Anna Beatriz Ribeiro Paiva Netto
}

São Paulo. Vol. 23, 2020

Artigo Original
Resumo: $O$ presente trabalho visa investigar como é a visão de habitantes da Zona Rural de São João del-Rei sobre o ambiente que os cerca e sobre as políticas públicas para a região. A metodologia utilizada tem por base a Epistemologia Qualitativa, sendo o foco na subjetividade dos participantes. Foram utilizadas entrevistas a partir da história de vida de onze participantes de seis comunidades rurais. A análise dos dados foi realizada a partir de conceitos da Psicologia Ambiental e do Modelo Bioecológico de Desenvolvimento Humano. Os resultados indicaram que os moradores se veem como habitantes de zonas rurais, esses descreveram as políticas públicas existentes e apontaram para as necessidades encontradas nesse contexto. Considera-se a necessidade de formulação de políticas públicas adequadas para a realidade apresentada.

Palavras-chave: Zona rural; Psicologia Ambiental; Políticas Públicas; Psicologia do Desenvolvimento.

Como citar: SANTOS, L. M. M. et al. Public Policies in the Rural Area of São João del-Rei: An inhabitants' view. Ambiente \& Sociedade. São Paulo, v. 23, p. 1-19, 2020. 


\title{
Políticas Públicas en la Zona Rural de São João del-Rei: Una visión de sus habitantes
}

\author{
Larissa Medeiros Marinho dos Santos \\ Johnny da Costa Barbosa \\ Rodrigo Meireles dos Santos \\ Anna Beatriz Ribeiro Paiva Netto
}

São Paulo. Vol. 23, 2020

Artículo original
Resumen: Este estudio tiene como objetivo investigar cómo es la visión de los habitantes de La Zona Rural del São João del-Rei sobre el ambiente que los rodea y sobre las políticas públicas para la región. La metodología utilizada se basa en la Epistemología Cualitativa, centrándose en la subjetividad de los participantes. Se realizaron entrevistas sobre la historia de vida de once participantes de seis comunidades rurales. El análisis de los datos se basó en los conceptos de la psicología ambiental y el modelo bioecológico de desarrollo humano. Los resultados indicaron que los habitantes se ven como habitantes de zonas rurales, éstos describieron las políticas públicas existentes y apuntar a las necesidades encontradas en ese contexto. Se considera la necesidad de formular políticas públicas adecuadas para la realidad presentada.

Palabras-clave: Zona rural; Psicología Ambiental; Políticas públicas; Psicología del Desarrollo.

Como citar: SANTOS, L. M. et. al. Políticas Públicas en la Zona Rural de São João del-Rei: Una visión de sus habitantes. Ambiente $\mathbb{\&}$ Sociedade. São Paulo, v. 23, p. 1-19, 2020.

DOI: http://dx.doi.org/10.1590/1809-4422asoc20180163r3vu2020L5AO 